models using generalized linear models with binomial link function. In model 1 we adjusted for age, sex and cell counts, in model 2 we additionally adjusted for BMI. We report effect estimate(beta) per standard deviation (SD) change in protein levels with $95 \%$ Confidence Interval $(\mathrm{Cl})$ and nominal p-value (significance level<0.05) for each protein. All statistical analyses were performed in $\mathrm{R}$ version 3.5.2.

Results: We found in total 56 proteins that were significantly associated with one or more OA-outcomes at nominal level. Figure 1 illustrates the 19 significant associations for severity of hand OA ordered by significance level (most significant at top). We observed a very robust association between the level of circulating Cartilage acidic protein 1 (CRTAC1) and severity of $\mathrm{OA}$ in the knee $(\beta=0.16,95 \% \mathrm{Cl} 0.09-0.23, \mathrm{p}=0.000013$, FDR-corrected $\mathrm{P}: 0.0011)$ hand $(\beta=0.086,95 \% \mathrm{Cl} 0.03-0.14, p=0.00085$, FDR-corrected $\mathrm{P}$ : $0.0252)$, while a similar trend was seen in hip $(\beta=0.08,95 \% \mathrm{Cl}-0.02-0.18$, $p=0.12$ ), although power in hip was limited in our study. The association with CRTAC1was also found for progression in knee $(\beta=0.21,95 \% \mathrm{Cl} 0.03$ $0.36, p=0.0156$, FDR-corrected $\mathrm{P}>0.2)$ and hip $(\beta=0.18,95 \% \mathrm{Cl}-0.01-0.38$, $p=0.0624$, FDR-corrected $P>0.9$ ). These associations were independent of BMI. Among the findings were several other promising biomarkers, e.g. MMP-10, which we observed to be associated with severity of hand OA $(\beta=-0.09,95 \% \mathrm{Cl}-0.15--0.04, p=0.00067$, FDR-corrected $\mathrm{P}: 0.0383)$ and progression of knee OA $(\beta=-0.24,95 \% \mathrm{Cl}-0.42--0.06, p=0.0073$, FDR-corrected $\mathrm{P}>0.1)$. Additionally, COMP, a well-known biomarker for $\mathrm{OA}$, was also found significant for $\mathrm{OA}$ severity in hand $(\beta=0.10,95 \% \mathrm{Cl} 0.05-0.16$, $p<0.001$, FDR-corrected $P: 0.0043)$ and knee $(\beta=0.09,95 \% \mathrm{Cl} 0.02-0.17$, $\mathrm{p}=0.01$, FDR-corrected $\mathrm{P}>0.2$ ).

Conclusion: We identified the CRTAC1 protein as a robust, promising biomarker for osteoarthritis severity and progression. This protein is a glycosylated extracellular matrix protein that is found in the interterritorial matrix of articular deep zone cartilage. This protein can also be used to distinguish chondrocytes from osteoblasts and mesenchymal stem cells in culture. This suggests that CRTAC1-levels reflects a cartilage-specific process in the joint. Such a biomarker might be useful for targeting the right patients for clinical trials and designing novel therapies for OA.

Disclosure of Interests: Ingrid Szilagyi: None declared, Costanza Vallerga: None declared, J.H. Waarsing: None declared, Dieuwke Schiphof: None declared, S.M.A. Bierma-Zeinstra Consultant of: Pfizer, one day consultancy, Joyce Van Meurs: None declared

DOI: 10.1136/annrheumdis-2021-eular.1888

\section{OP0112 FACTORS ASSOCIATED WITH OSTEOPOROSIS CARE OF MEN: A REAL-LIFE STUDY ON A NATION-WIDE DATASET}

G. Adami ${ }^{1}$, D. Gatti ${ }^{1}$, A. Giollo ${ }^{1}$, E. Bertoldo ${ }^{1}$, O. Viapiana ${ }^{1}$, P. Olivi ${ }^{2}$, A. Fassio ${ }^{1}$, M. Rossini ${ }^{1}$. 'University of Verona, Rheumatology Unit, Verona, Italy; ${ }^{2}$ University of Verona, Orthopedic Unit, Verona, Italy

Background: Male osteoporosis is associated with an important clinical and economic burden worldwide. Notwithstanding that, undertreatment of men with osteoporosis is common. Understanding the factors associated with less osteoporosis care utilization might help define future intervention to improve access of men to osteoporosis care.

Objectives: The aim of the study was to describe the factors associated with osteoporosis care in men.

Methods: We conducted a retrospective analysis of a nation-wide cohort (DeFRACalc79 database). DeFRACalc79 is a tool that estimates the fracture risk considering clinical and densitometric risk factors, including the presence of prior hip or vertebral and non-vertebral or non-hip fractures. We compared the clinical characteristics of male individuals with an age matched cohort of women. Propensity score generation with 2:1 matching for female and male patients was performed matching the cohorts for age, generating propensity estimates with a logistic regression model.

Results: We analyzed a sample of 4,902 men at high risk of osteoporosis. We found that the factors associated to osteoporosis care utilization in men were: the presence of comorbidities (OR 1.939, 95\% Cl 1.799-2.090), adjuvant hormonal therapy for prostate cancer (OR $1.482,95 \% \mathrm{Cl} 1.315-1.670$ ), the presence of vertebral or hip fractures (OR 1.490, 95\% Cl 1.378-1.611) and glucocorticoid treatment (OR 2.573, 95\% Cl 2.274-2.832) (Table 1)

Conclusion: We found that men accessed osteoporosis care with more severe osteoporosis and/or with a diagnosis of secondary osteoporosis. Male osteoporosis remains largely underdiagnosed with a dramatic latency in osteoporosis care utilization compared to women.

Disclosure of Interests: None declared

DOI: 10.1136/annrheumdis-2021-eular.257
Table 1. Clinical and densitometric characteristics of the study population and age-matched cohort of women

\begin{tabular}{|c|c|c|c|}
\hline & $\begin{array}{c}\text { Men } \\
(n=4,902)\end{array}$ & $\begin{array}{l}\text { Women } \\
(n=9,804)\end{array}$ & $\begin{array}{l}\text { OR }(95 \% \mathrm{Cl})- \\
\text { p value }\end{array}$ \\
\hline Age ( \pm SD) & $65.1( \pm 14.2)$ & $65.1( \pm 14.2)$ & NS \\
\hline BMI ( $($ SD) & $25.31( \pm 4.91)$ & $24.07( \pm 4.85)$ & $<0.0001$ \\
\hline Lumbar spine T-score ( $\pm \mathrm{SD})$ & $-2.13( \pm 1.37)$ & $-2.51( \pm 1.15)$ & $<0.0001$ \\
\hline Osteoporosis at lumbar spine (\%) & $2,601(53.1 \%)$ & $5,948(60.7 \%)$ & 0.733 \\
\hline Femoral neck T-score $( \pm \mathrm{SD})$ & $-1.93( \pm 1.04)$ & $-2.19( \pm 0.91)$ & $\begin{array}{c}(0.684-0.785) \\
<0.0001\end{array}$ \\
\hline Osteoporosis at femoral neck (\%) & $1,412(28.8 \%)$ & $3,936(40.1 \%)$ & $\begin{array}{c}0.603 \\
(0.560-0.649)\end{array}$ \\
\hline$\%$ 10-year risk of fracture $( \pm S D)$ & $22.77( \pm 21.05)$ & $20.26( \pm 4.85)$ & $<0.0001$ \\
\hline $\begin{array}{l}\text { Family history of fragility } \\
\text { fracture (\%) }\end{array}$ & $891(18.2 \%)$ & $2,379(24.3 \%)$ & $\begin{array}{c}0.693 \\
(0.636-0.756)\end{array}$ \\
\hline Secondary osteoporosis (\%) & $2,415(49.3 \%)$ & $3,092(31.5 \%)$ & $\begin{array}{c}2.108 \\
(1.965-2.262)\end{array}$ \\
\hline $\begin{array}{l}\text { Glucocorticoids } \geq 5 \mathrm{mg} / \text { day }>3 \\
\text { months }(\%)\end{array}$ & $768(17.4 \%)$ & $694(7.7 \%)$ & $\begin{array}{c}2.573 \\
(2.274-2.832)\end{array}$ \\
\hline $\begin{array}{c}\text { Glucocorticoids } \geq 5 \mathrm{mg} / \text { day } \geq 3 \\
\text { months }<12 \text { months }(\%)\end{array}$ & $74(2.0 \%)$ & $72(0.9 \%)$ & $\begin{array}{c}2.357 \\
(1.700-3.267)\end{array}$ \\
\hline $\begin{array}{l}\text { Glucocorticoids } \geq 5 \mathrm{mg} / \text { day } \geq 12 \\
\text { months (\%) }\end{array}$ & $119(3.2 \%)$ & $138(1.6 \%)$ & $\begin{array}{c}1.977 \\
(1.543-2.534)\end{array}$ \\
\hline $\begin{array}{l}\text { Adjuvant hormonal therapy for breast } \\
\text { cancer or prostate cancer (\%) }\end{array}$ & $495(12.0 \%)$ & $766(8.4 \%)$ & $\begin{array}{c}1.482 \\
(1.315-1.670)\end{array}$ \\
\hline Comorbidities (\%) & $1,778(36.3 \%)$ & $2,225(22.7 \%)$ & $\begin{array}{c}1.939 \\
(1.799-2.090)\end{array}$ \\
\hline Rheumatoid arthritis (\%) & $303(8.8 \%)$ & $511(6.3 \%)$ & $\begin{array}{c}1.439 \\
(1.241-1.668)\end{array}$ \\
\hline Psoriatic arthritis (\%) & $59(1.9 \%)$ & $103(1.3)$ & $\begin{array}{c}1.390 \\
(1.006-1.919)\end{array}$ \\
\hline $\begin{array}{l}\text { Systemic lupus } \\
\text { erythematosus (\%) }\end{array}$ & $22(0.7 \%)$ & $77(1.0 \%)$ & $\begin{array}{c}0.693 \\
(0.431-1.115)\end{array}$ \\
\hline Systemic sclerosis (\%) & $9(0.3 \%)$ & $60(0.8 \%)$ & $\begin{array}{c}0.364 \\
(0.180-0.734)\end{array}$ \\
\hline Other rheumatic diseases (\%) & $173(5.2 \%)$ & $310(3.9 \%)$ & $\begin{array}{c}1.354 \\
(1.119-1.638)\end{array}$ \\
\hline Inflammatory bowel diseases (\%) & $144(2.7 \%)$ & $126(1.6 \%)$ & $\begin{array}{c}2.773 \\
(2.175-3.534)\end{array}$ \\
\hline $\begin{array}{l}\text { Chronic obstructive pulmonary } \\
\text { disease (\%) }\end{array}$ & $281(8.3 \%)$ & $277(3.5 \%)$ & $\begin{array}{c}2.461 \\
(2.074-2.920)\end{array}$ \\
\hline Diabetes (\%) & $441(12.4 \%)$ & $478(5.9 \%)$ & $\begin{array}{c}2.238 \\
(1.954-2.564)\end{array}$ \\
\hline Neurological diseases (\%) & $236(7.0 \%)$ & $260(3.3 \%)$ & $\begin{array}{c}2.202 \\
(1.837-2.639)\end{array}$ \\
\hline HIV infection (\%) & $110(3.4 \%)$ & $23(0.3 \%)$ & $\begin{array}{c}11.603 \\
(7.389-18.221)\end{array}$ \\
\hline Vertebral or hip fractures (\%) & $1,434(29.3 \%)$ & $2,130(21.7 \%)$ & $\begin{array}{c}1.490 \\
(1.378-1.611)\end{array}$ \\
\hline Non-vertebral, non-hip fractures (\%) & $534(10.9 \%)$ & $1,477(15.1 \%)$ & $\begin{array}{c}0.689 \\
(0.620-0.766)\end{array}$ \\
\hline
\end{tabular}

OP0113 FEMALE REPRODUCTIVE FACTORS AND RISK OF JOINT REPLACEMENT ARTHROPLASTY OF KNEE AND HIP DUE TO OSTEOARTHRITIS IN POSTMENOPAUSAL WOMEN: A NATIONWIDE COHORT STUDY OF 1.36 MILLION WOMEN

Y. Eun ${ }^{1}$, J. E. Yoo ${ }^{2}$, K. D. $\mathrm{Han}^{3}$, D. H. Kim³ ${ }^{3}$, J. Lee ${ }^{1}$, D. Y. Lee ${ }^{4}$, D. H. Lee H. Kim ${ }^{6}$, D. W. Shin ${ }^{7} .{ }^{1}$ Samsung Medical Center, Sungkyunkwan University School of Medicine, Department of Medicine, Seoul, Korea, Rep. of (South Korea); ${ }^{2}$ Healthcare System Gangnam Center, Seoul National University Hospital, Department of Family Medicine, Seoul, Korea, Rep. of (South Korea);

${ }^{3}$ Soongsil University, Department of Statistics and Actuarial Science, Seoul, Korea, Rep. of (South Korea); ${ }^{4}$ Samsung Medical Center, Sungkyunkwan University School of Medicine, Department of Obstetrics and Gynecology, Seoul, Korea, Rep. of (South Korea); ${ }^{5}$ Samsung Medical Center, Sungkyunkwan University School of Medicine, Department of Orthopedic Surgery, Seoul, Korea, Rep. of (South Korea); ${ }^{6}$ Samsung Medical Center, Sungkyunkwan University School of Medicine, Department of Medical Humanities, Seoul, Korea, Rep. of (South Korea); ${ }^{7}$ Samsung Medical Center, Sungkyunkwan University School of Medicine, Department of Family Medicine and Supportive Care Centre, Seoul, Korea, Rep. of (South Korea)

Background: Previous studies on the link between female reproductive factors and osteoarthritis (OA) have shown conflicting results.

Objectives: This study attempted to explore the association between reproductive factors and joint replacement arthroplasty of knee (TKRA) and hip (THRA) in a large nationwide population-based cohort of postmenopausal women. Methods: $1,218,257$ subjects who participated in national health examination in 2009 were included in the study. The study outcomes is incident THRA or TKRA 